\title{
Three-dimensional finite element analysis of mandibular overdentures with different implant positions and attachment types
}

\author{
Josué Ricardo Broilo ${ }^{a}$, Evandro Afonso Sartoria , Luiz Oscar Honorato Mariano ${ }^{a}$, Leandro Corso ${ }^{\mathrm{b}}$, \\ Rosemary Sadami Arai Shinkaic
}

\begin{abstract}
OBJECTIVE: This 3-D FEA study compared the stress distribution in two-implant mandibular overdentures as a function of implant position and attachment system (LA: locator attachment vs. BA: ball attachment).

METHODS: Four models of mandibular overdentures were tested: M1-LA - with implants at the canine regions (standard implant position) and LA; M2-LA - with implants placed at the first premolar regions (distalized implant position) and LA; M1-BA - with standard implant position and BA; and M2-BA - with distalized implant position and BA. The geometric models were converted into finite element models. A $100 \mathrm{~N}$ axial load was applied at the first molar region. The von-Mises stress distribution was compared in selected points.

RESULTS: The models with BA had pattern of stress distribution was more uniform along the implant axis than the ones with LA, although the stress magnitude was larger. The largest area of von Mises stresses on the alveolar ridge was in the models with standard implant distribution.

CONCLUSION: The findings showed that the models with BA had better biomechanical behavior than the ones with LA. For both types of attachment, the models with increased inter-implant distance presented a smaller area of stress distribution in the perimplant cortical bone tissue than the standard implant position.
\end{abstract}

Keywords: dental implants; implant-supported overdenture; biomechanics; finite element analysis.

\section{Análise de elementos finitos em 3D de sobredentaduras mandibulares com diferentes posições de implante e tipos de encaixe}

\section{RESUMO}

OBJETIVO: Este estudo de análise de elementos finitos em 3-D comparou a distribuição de tensão em sobredentaduras suportadas por implante em função da posição do implante e do sistema de encaixe (AA: tipo "locator" vs. BA: tipo "bola")

METODOLOGIA: Foram testados quatro modelos 3-D de sobredentadura com implante mandibular: M1-LA com implantes nas regiões dos dentes caninos (posição padrão dos implantes) e LA; M2-LA - com implantes nas regiões dos dentes primeiros pré-molares (posição distalizada dos implantes) e LA; M1-BA - com posição padrão de implante e BA; e M2-BA - com posição distalizada dos implantes e BA. Os modelos geométricos foram convertidos em modelos de elementos finitos. Uma carga axial de $100 \mathrm{~N}$ foi aplicada na primeira região molar. A distribuição de estresses von Mises foi comparada em pontos selecionados.

RESULTADOS: Os modelos com BA apresentaram padrão de distribuição de estresse mais uniforme ao longo do eixo do implante do que os modelos com LA, embora a magnitude do estresse tenha sido maior. A maior área de tensões no rebordo alveolar ocorreu nos modelos com posição padrão de implantes.

CONCLUSÃO: Os resultados sugerem que os modelos com BA apresentaram melhor comportamento biomecânico do que aqueles com LA. Para ambos os encaixes, implantes distalizados apresentam uma menor área de distribuição de estresse no tecido ósseo cortical do que posicionamento padrão dos implantes.

Palavras-chave: implantes dentários; sobredentadura sobre implantes; biomecânica; análise de elementos finitos.
${ }^{a}$ MSc in Prosthodontics, Graduate Program in Dentistry, Pontifical Catholic University of Rio Grande do Sul, Porto Alegre, RS, Brazil.

${ }^{b}$ Assistant Professor, Department of Engineering University of Caxias do Sul, Caxias do Sul, RS, Brazil 'Professor, Department of Prosthodontics, Pontifical Catholic University of Rio Grande do Sul, Porto Alegre, RS, Brazil 


\section{INTRODUCTION}

Two-implant overdentures are considered the first choice for treatment of edentulous mandibles due to more efficient retention, stability, masticatory performance, and patients' satisfaction and quality of life in comparison with conventional complete dentures $[1,2]$. In the traditional overdenture protocol, two implants are placed between the canines in the symphysis region of the mandible. The installation of two independent implants in the premolar region would allow larger rotation of the mandibular overdenture in comparison with the insertion of implants in the canines region. However, the more posterior location of the implants should reduce the lever arm and diminish the denture displacement under masticatory loading in the posterior teeth.

The stability and retention of overdentures are promoted by the implant-attachment-prosthesis connection systems. There are several types of attachments available in the worldwide market, and the most popular are ball, o'ring, stud, and magnet $[3,4]$. In the literature, the biomechanical behavior of these systems was studied mainly by means of the prosthesis retention [5-12] or the bone-implant-abutmentattachment-prosthesis interaction [6,13-16]. However, there are still limited studies that have addressed the optimization of this type of treatment with alternative implant localization designs across attachment systems $[3,4]$.

The biomechanical behavior of implant-supported implants, considering the tensions generated at the boneimplant-abutment-prosthesis interfaces can be evaluated through different methods: photoelastic analysis [6], extensometry $[7,8,15]$, and finite element analysis $[11,13$, 14,16]. According to Tanino et al. [16], the photoelastic analysis is limited in the quantification of the information, and the extensometry is influenced by the size of the extensometer. The 3-D finite element analysis (FEA) can simulate the stress dynamics and calculate the tensions and displacements in a system model. This allows the analysis of complex loading conditions in the prosthesis, attachments and jawbone, which would be clinical or experimentally impossible.

Limited scientific evidence is still available regarding the distribution of implants in the edentulous jaw in combination with different attachments, which is relevant for the biomechanic behavior of different treatment choices. Therefore, this 3-D FEA study compared the stress distribution on implant-supported overdenture as a function of different implant positions and attachment type (locator attachment vs. ball attachment). The working hypothesis is that the arch-distribution of the implants and the type of attachment affect the stresses in two-implant mandibular overdentures.

\section{METHODS}

The study design is a numeric simulation using 3-D FEA.

\section{Continuous geometric models}

Four 3-D geometric models were built with the individual solid models of two cylindrical dental implants $4.1 \times 11.5$ mm (3i Implant Innovations, Palm Beach, Florida, USA), two attachments (an anchor-type attachment: Locator ${ }^{\circledR}, 3 \mathrm{i}$ Implant Innovations, Palm Beach, Florida, USA; and a ball attachment: DalRo ${ }^{\circledR}, 3 i$ Implant Innovations, Palm Beach, Florida, USA), one overdenture, simulated $3 \mathrm{~mm}$-thick mucosa, and one mandible. Both attachment types had 4-mm height (Figures 1 and 2).

The individual images were obtained by means of laser scanning, computed tomography of the mandible (seventy $1 \mathrm{~mm}$-thick slices), and computer-aided design using the softwares Matlab ${ }^{\circledR}$ (The MathWorks, Natick, Massachusetts, USA), Geomagic ${ }^{\circledR} 7.0$ (Raindrop, Research Triangle Park, USA), Rhynoceros 3D ${ }^{\circledR} 3.0$ (McNeel \& Associates, Seattle, USA), and SolidWorks ${ }^{\circledR}$ (SolidWorks Corporation, Concord, Massachusetts, USA). A detailed description of geometric modeling is provided by Mariano et al. [17].

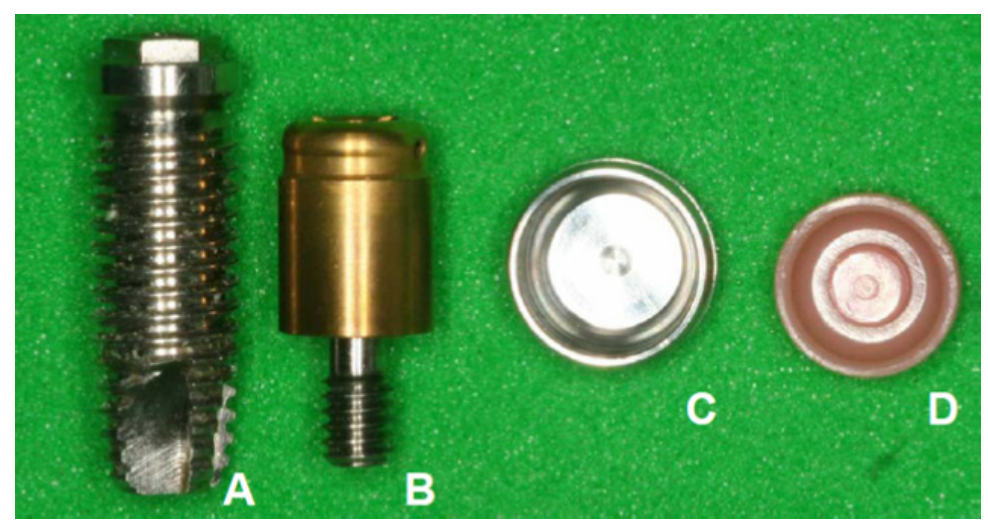

Figure 1. Locator attachment: A - cylindric implant; B - Locator ${ }^{\circledR}$ Attachment, 4-mm height (male component); C - locator female component; D - PTFE (resilient cap).

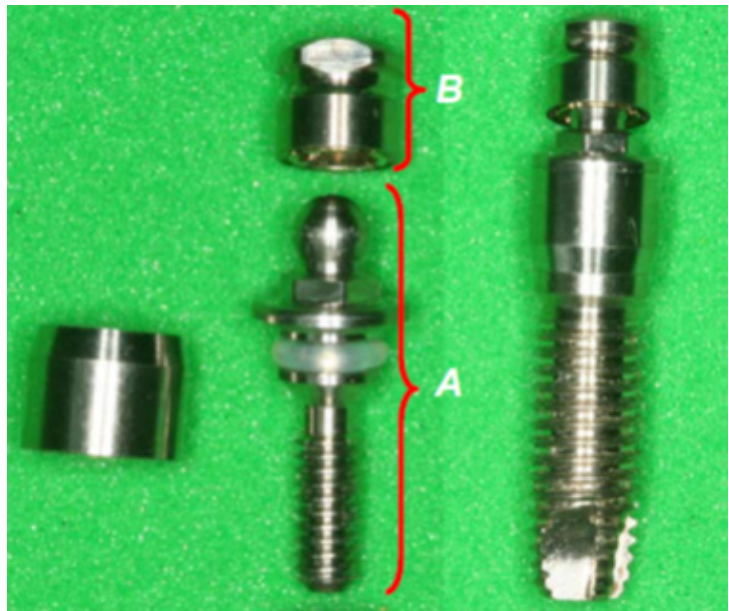

Figure 2. Ball Attchment Dal Ro ${ }^{\circledR}$, 4-mm height: A - male component; $\mathbf{B}$ - female component. 
Firstly, two models of implant distribution in the mandible were assembled:

- a standard implant position model (M1): the implant external hexagon was placed in the region of mandibular canines (teeth 33 and 43), with inter-implant distance of $16 \mathrm{~mm}$ from center to center of the two implants [18], and

- a distalized implant position model (M2): the implant external hexagon was placed in the region of mandibular premolars (teeth 34 and 44), with inter-implant distance of $32 \mathrm{~mm}$ from center to center of the two implants.

The two tested attachment types were built onto the models M1 and M2 yielding four models (Figure 3): M1 with locator attachment (M1-LA), M2 with locator attachment (M2-LA), M1 with ball attachment (M1-BA), and M2 with ball attachment (M2-BA).

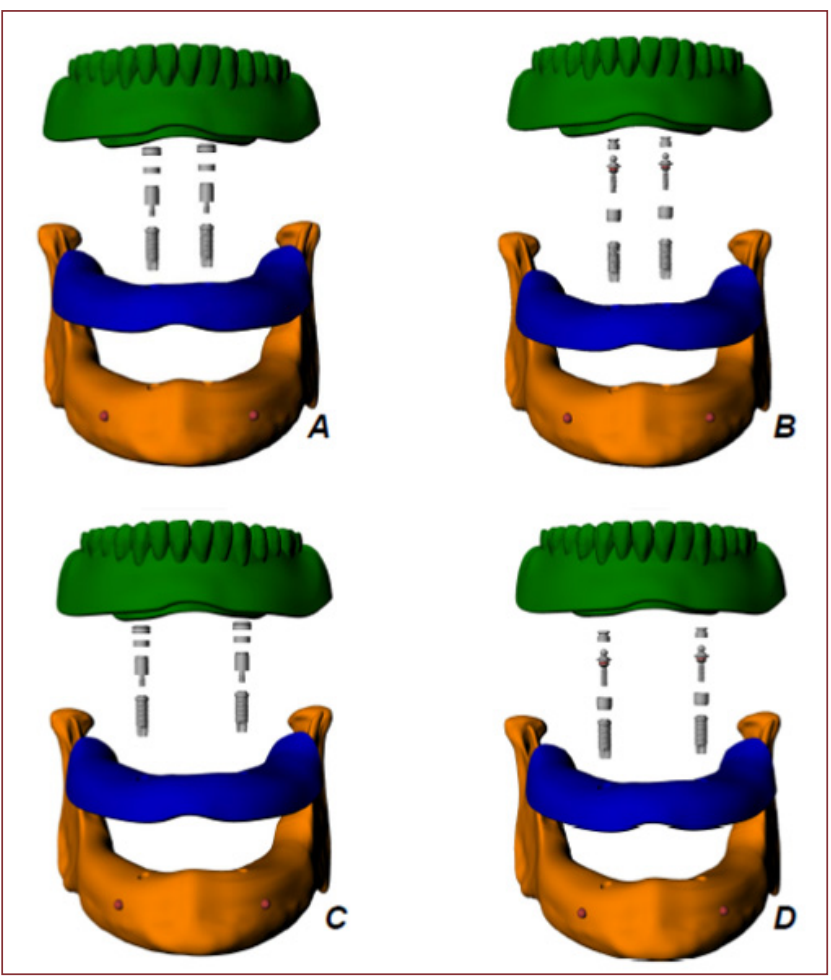

Figure 3. Geometric solid models (exploded view): A - standard implant position model and locator-type attachment (M1-LA); B - distalized implant position model and locator-type attachment (M2-LA); C - standard implant position model and ball-type attachment (M1-BA); D - distalized implant position model and ball-type attachment (M2-BA).

\section{3-D finite element models and analyses}

Four 3-D FEA models were generated by importing the solid models into the software Ansys 10.0 (Ansys Inc., Houston, USA) and using 10-node tetrahedral structural solid p-elements. The mechanical elastic properties of bone, implants, attachments, simulated mucosa, and denture are displayed in Table 1. The materials were considered homogeneous, isotropic, and linearly elastic. A perfect contact between bone and implants (100\% osseointegration) was assumed [11]. Boundary conditions included constraining three degrees of freedom at each of the nodes located at the mandibular condyles.

The models were loaded by an axial vertical load of $100 \mathrm{~N}$ applied on the right first molar, using a masticatory bolus simulation modeled as a rigid semi-sphere placed over the denture tooth $[11,17]$. The von Mises stresses were qualitatively analyzed in selected areas.

Table 1. Mechanical elastic properties of bone and materials used in the anisotropic models (Daas et al. (2007).5

\begin{tabular}{lcc}
\hline & $\begin{array}{c}\text { Young's } \\
\text { modulus (MPa) }\end{array}$ & Poisson's ratio \\
\hline Cortical bone & 13,700 & 0.3 \\
Cancellous bone & 1,370 & 0.3 \\
Mucosa & 1 & 0.37 \\
Mandibular nerve & 0.1 & 0.3 \\
Overdenture (acrylic resin) & 4,500 & 0.35 \\
Implant (titanium) & 135,000 & 0.3 \\
Screw (titanium) & 114,000 & 0.3 \\
Attachment (titanium) & 114,000 & 0.3 \\
PTPE attachment component & 19,000 & 0.3 \\
\hline
\end{tabular}

\section{RESULTS}

\section{Working side: stresses in the implant- attachment assembly (Figure 4)}

For the locator attachment models (models M1-LA and M2-LA), the area of stress distribution were similar for M1 and M2, with the largest areas of stress observed in the middle and cervical thirds of the implant, male locator attachment, and female locator attachment. M2 showed slightly higher stresses than M1, mainly at the center of the attachment (male) and at the implant platform.

For the ball attachments and implant (models M1-BA and M2-BA), the area of stress distribution were similar for M1 and M2, with the largest areas of stress observed in the body of the ball attachment (male component) and in the implant platform (Figure 4). However, M2 showed slightly higher stresses than M1.

Non-working side: stresses in the implantattachment assembly (Figure 5)

For the locator attachment models (models M1-LA and M2-LA), M1 showed a larger area of stress distribution than M2, and the highest stresses were seen at the cervical region of the implant and locator attachment.

For the ball attachments and implant (models M1-BA and M2-BA), M2 presented slightly higher stress distribution area than $\mathrm{M} 1$. 

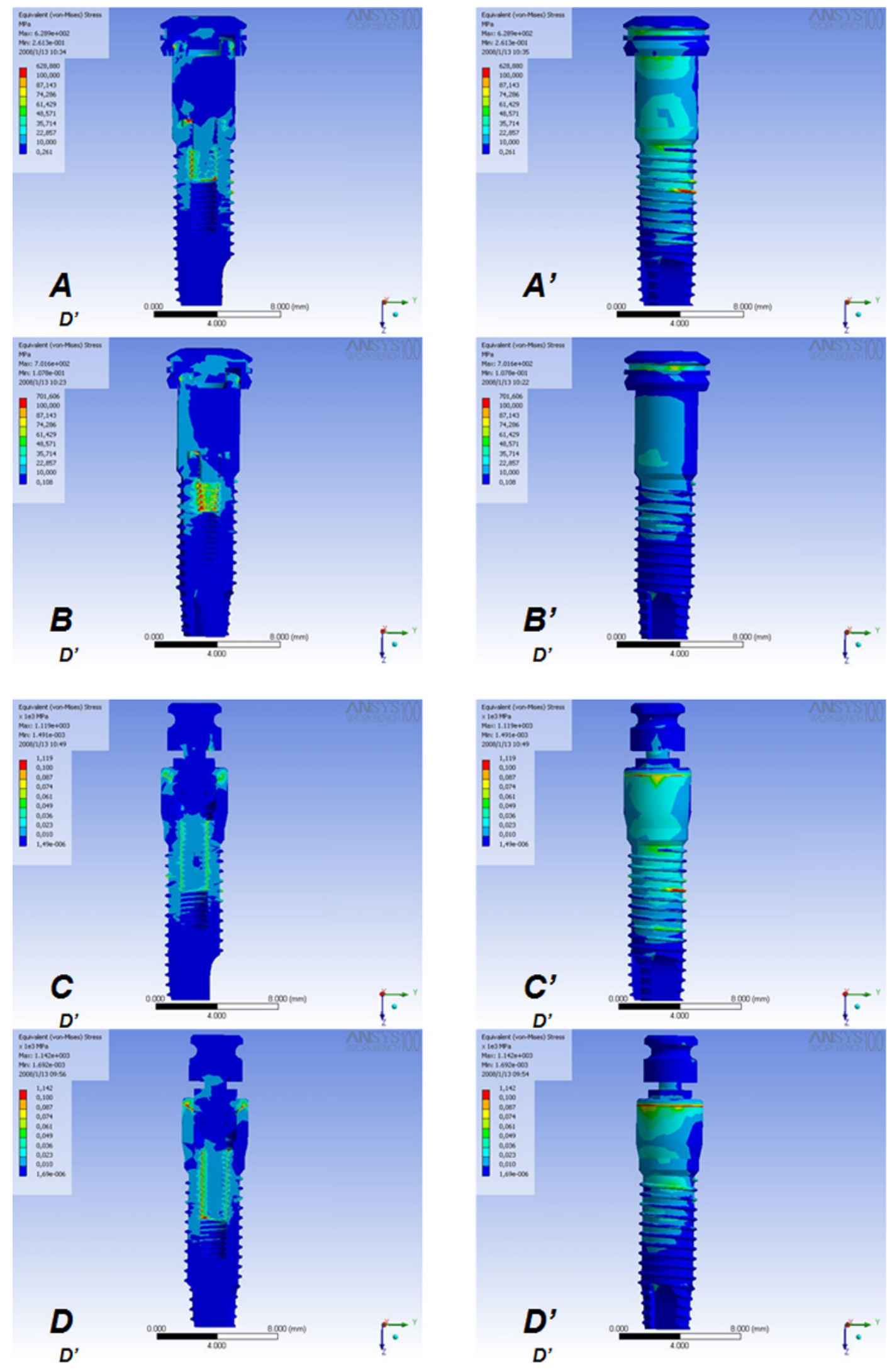

Figure 4. Stress distribution in the implant-attachment assembly, on the working side: $\mathbf{A}$ - internal view of M1-LA; A'- external view of M1-LA; $\mathbf{B}$ - internal view of M2-LA; $\mathbf{B}^{\prime}$ - external view of M2-LA; $\mathbf{C}$ - internal view of M1-BA; $\mathbf{C}^{\prime}$ external view of M1-BA; D - internal view of M2-BA; D'- external view of M2-BA. 


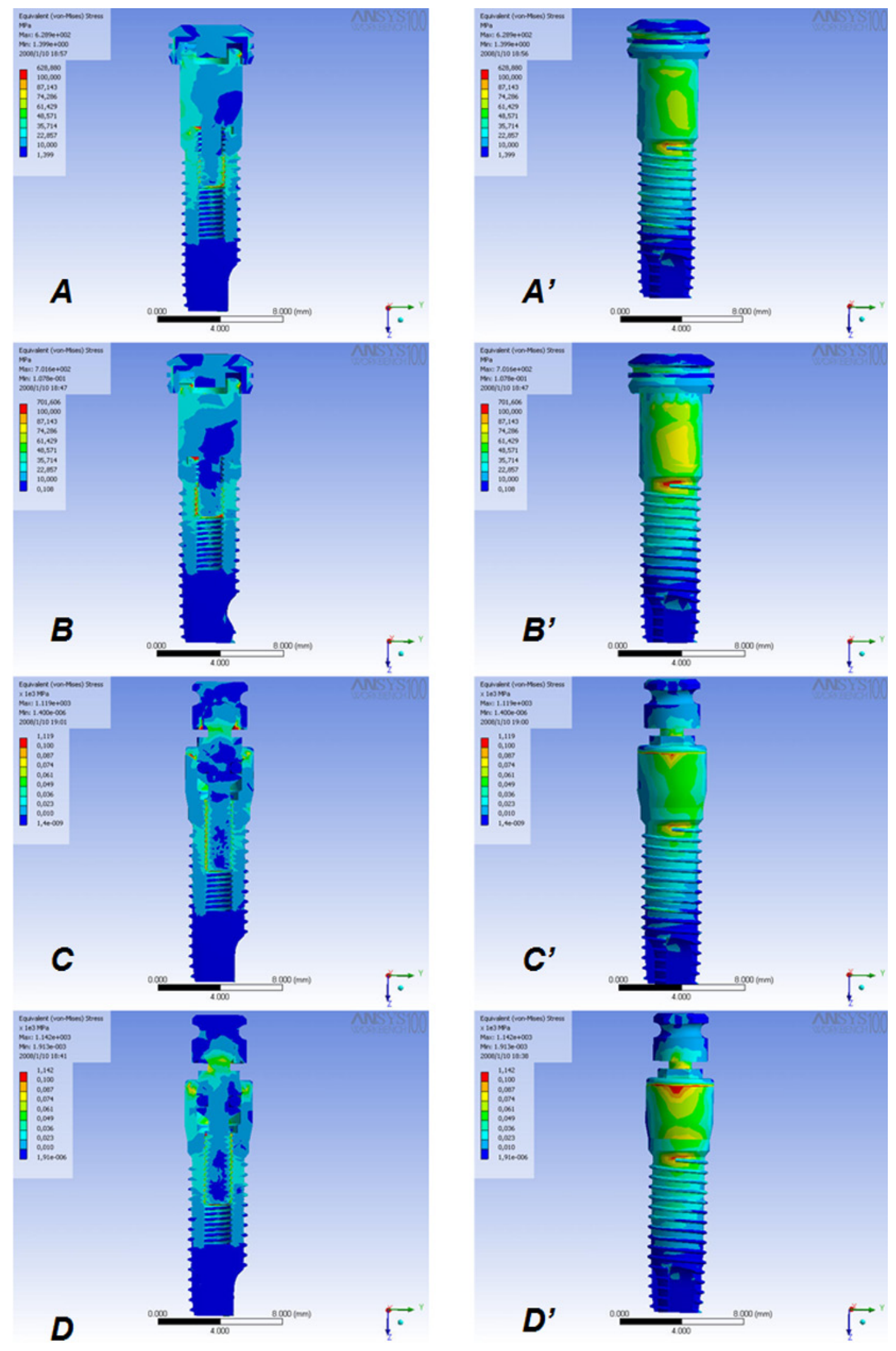

Figure 5. Stress distribution in the implant-attachment assembly, on the non-working side: $\mathbf{A}$ - internal view of M1-LA; $\mathbf{A}^{\prime}$ - external view of M1-LA; $\mathbf{B}$ - internal view of M2-LA; $\mathbf{B}^{\prime}$ - external view of M2-LA; C - internal view of M1-BA; $\mathbf{C}^{\prime}$ - external view of M1-BA; D - internal view of M2-BA; $\mathbf{D}^{\prime}$ - external view of M2-BA. 

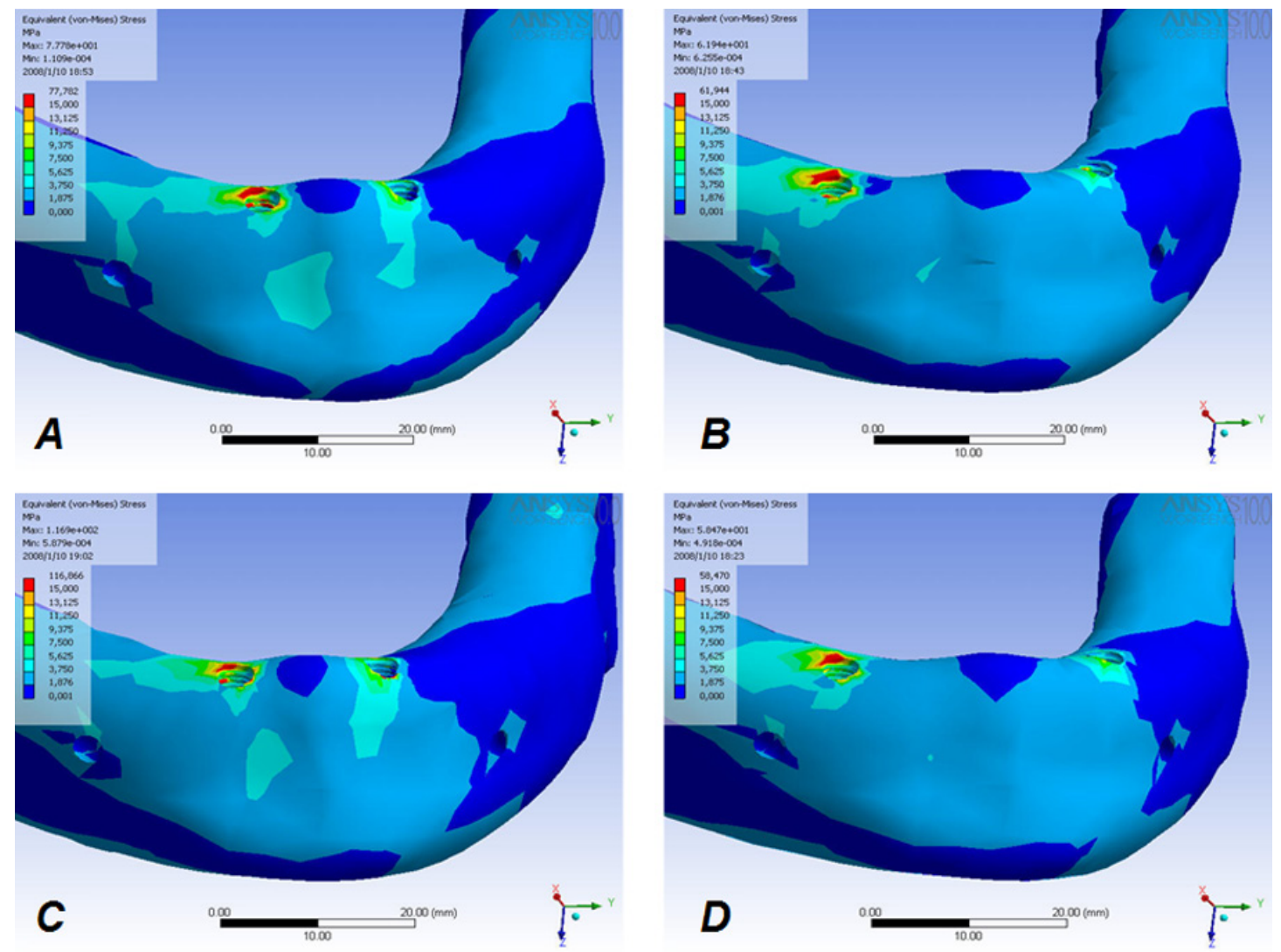

Figure 6. Distribution of stresses on the alveolar ridge according to the tested models: $\mathbf{A}-\mathrm{M} 1-\mathrm{LA} ; \mathbf{B}-\mathrm{M} 2-\mathrm{LA}$; C - M1-BA; D - M2-BA.

\section{Stresses in the mandibular bone (Figure 6)}

All four models showed the largest concentration of stresses on the working side, mainly in the cortical bone at the distal region of the implant. M1 with locator or ball attachments showed larger stress area in the mandibular symphysis region when compared to M2, with a vertical distribution pattern. In the interimplant region and the posterior alveolar ridge, the stress distribution was similar in all four models. On the non-working side, M2 showed smaller areas of stress than M1 for both locator and ball attachments.

\section{DISCUSSION}

This study showed that the distalized position of implants for two-implant overdentures presented a smaller area of stress distribution than the conventional inter-canine position of implants. In addition, the ball-type attachment seems to be more biomechanically favorable than the locator-type attachments because the stress distribution pattern was more uniform along the implant long axis, although the stress magnitude were slightly higher. The two non-splint retentive systems were chosen due to the simplicity of the clinical and laboratorial technique, and the lack of studies on their biomechanical behavior as a function of the implant position.

The present findings suggest that the placement of implants in the premolar region is a viable option for the edentulous jaw rehabilitation with non-splint retention systems in two-implant overdentures. Through the 3-D FEA, the compressive force exerted on the support tissues also showed a more favorable patter of stress distribution when the implants were placed more posteriorly in the arch. There was a decrease in the areas of high stresses in the entire mandibular body, mainly in the anterior portion, as well as a horizontal pattern of stress distribution. Vertical stresses overtime could promote more fatigue of the retention systems. In an in vitro study [19], the interimplant distance $(19,23$, and $29 \mathrm{~mm})$ was found to play a significant role only in the 6-month fatigue retention of the Hader bar with red and yellow clips.

The conventional position of implants in the inter-canine region, regardless of the option of the retention system, may have some longitudinal risks due to the hinge effect [20]. The principles of classical biomechanics suggest the possibility of distalization of implants placed at first premolar regions (corresponding to teeth 34 and 44 or immediately anterior 
to the mentonian foramen) in order to decrease the lever arm. In addition, distalizing the implants would increase the resistance arm. As the tendency of rotation or displacement of the denture decreases with the implant distalization, it might result in even greater levels of patient satisfaction.

On the working-side, the implant-attachment assembly showed the highest stress concentration in the attachment body (male component) and the implant platform, for all four models tested. However, slightly larger areas of stress distribution occurred in the distalized implants models with both types of attachments. This may be due to the proximity of the point of load application or the adoption of perfect contact between the elements of the models. Although the ball attachment used was not resilient, the low stress concentration in the assemby was similar to the results found by Daas et al. [11]. Conversely, the nonworking side presented the largest areas of stress distribution with the ball attachment. However, the models with locator attachments presented a non-uniform distribution pattern of the stress along the implant long axis, which denotes a lower biomechanical performance than the ball attachment. These results are similar to the literature for the ball attachment using extensometry [15] and FEA [13] with implants placed in the conventional intercanine position. However, the stress distribution and values would be different with variation of magnitude and direction of forces, place of application of loading, and modulus of elasticity of the materials [16].

Many classic clinical protocols and innovative proposals lack scientific support and are guided by theoretical knowledge coupled with the clinical experience of surgeons and prosthodontists. In this 3-D FEA study, it was possible to simulate biomechanical behavior in different situations. In this way, it is possible to simulate complex conditions without risk to the patients and to evaluate the performance and the distribution of tensions in the support tissues with the aid of the predictive engineering. FEA has been used to analyze the distribution of stress and deformation in geometrically complex structures in dentistry. The predictive accuracy of FEA is influenced by the geometric details of the elements, the applied loads, the boundary conditions, and the material properties. The accuracy of the geometry of the models and the complexity of the system proposed in the study could be simulated with the aid of computational resources.

This study assumed several simplifications to build the models, which does not allow extrapolation of the present results to other situations. For example, the action of the muscles inserted in the mandible was not simulated, and the fixation points were adopted in the condylar processes. Despite these limitations of numeric simulation, the results suggest that alternative models with both attachments are clinically feasible for rehabilitation treatment for edentulous individuals. Further studies should analyze the stresses generated by different load angulation, nonlinear models, and dynamic loading, as well as in bone with different density. Integration with other areas, such as engineering, underscores the need to exchange information and technologies for the scientific advancement of dentistry, since clinical observations are not enough to support theoretical knowledge [14]. Thus, additional research with multidisciplinary efforts should optimize the predictability of the models for clinical treatment and innovation trends.

\section{CONCLUSIONS}

Within the findings and limitations of this study, the distalized distribution of implants with both ball and locator-type attachments showed a viable biomechanical behavior of two-implant mandibular overdentures. The ball attachment had better biomechanical behavior than the locator attachment as the pattern of stress distribution was more uniform along the implant axis.

\section{ACKNOWLEDGMENTS}

This study was partially supported by the Brazilian Ministry of Education graduate scholarship CAPES. We would like to thank Mr. Maico Thiessen Souza for his technical support for the development of all solid models.

\section{REFERENCES}

1. Das KP, Jahangiri L, Katz RV. The first-choice standard of care for an edentulous mandible: a Delphi method survey of academic prosthodontists in the United States. J Am Dent Assoc 2012;143:881-9. https://doi. org/10.14219/jada.archive.2012.0292

2. Thomason JM, Kelly SA, Bendkowski A, Ellis JS. Two implant retained overdentures--a review of the literature supporting the McGill and York consensus statements. J Dent 2012;40:22-34. https://doi.org/10.1016/j. jent.2011.08.017

3. Alsabeeha NH, Payne AG, Swain MV. Attachment systems for mandibular two-implant overdentures: a review of in vitro investigations on retention and wear features. Int J Prosthodont 2009;22:429-40.

4. Shah K, Yilmaz B, McGlumphy E. Fabrication of a mandibular implantsupported overdenture with a new attachment system: A review of current attachment systems. Int J Prosthodont 2017;30:245-7. https:// doi.org/10.11607/ijp.5068

5. Duyck J, Van Oosterwyck H, Vander Sloten J, De Cooman M, Puers R, Naert I. In vivo forces on oral implants supporting a mandibular overdenture: the influence of attachment system. Clin Oral Investig 1999;3:201-7. https:// doi.org/10.1007/s007840050102

6. Celik G, Uludag B. Photoelastic stress analysis of various retention mechanisms on 3-implant-retained mandibular overdentures. J Prosthet Dent 2007;97:229-35. https://doi.org/10.1016/j.prosdent.2007.02.006

7. Porter JA Jr, Petropoulos VC, Brunski JB. Comparison of load distribution for implant overdenture attachments. Int J Oral Maxillofac Implants 2002;17:651-62

8. van Kampen F, Cune M, van der Bilt A, Bosman F. Retention and postinsertion maintenance of bar-clip, ball and magnet attachments in mandibular implant overdenture treatment: an in vivo comparison after 3 months of function. Clin Oral Implants Res 2003;14:720-6. https://doi. org/10.1046/j.0905-7161.2003.00961.x

9. Chung KH, Chung CY, Cagna DR, Cronin RJ Jr. Retention characteristics of attachment systems for implant overdentures. J Prosthodont 2004;13: 221-6. https://doi.org/10.1111/j.1532-849X.2004.04042.x

10. van der Bilt A, van Kampen FM, Cune MS. Masticatory function with mandibular implant-supported overdentures fitted with different attachment types. Eur J Oral Sci 2006;114:191-6. https://doi.org/10.1111/ j.1600-0722.2006.00356.x

11. Daas M, Dubois G, Bonnet AS, Lipinski P, Rignon-Bret C. A complete finite element model of a mandibular implant-retained overdenture with two implants: Comparison between rigid and resilient attachment configurations. Med Eng Phys 2008;30:218-25. https://doi.org/10.1016/j. medengphy.2007.02.005

12. Rutkunas $\mathrm{V}$, Mizutani $\mathrm{H}$, Takahashi $\mathrm{H}$. Influence of attachment wear on retention of mandibular overdenture. J Oral Rehabil 2007;34:41-51. https:// doi.org/10.1111/j.1365-2842.2006.01640.x

13. Menicucci G, Lorenzetti M, Pera P, Preti G. Mandibular implant-retained overdenture: finite element analysis of two anchorage systems. Int J Oral Maxillofac Implants 1998;13:369-76 
14. Simşek B, Erkmen E, Yilmaz D, Eser A. Effects of different interimplant distances on the stress distribution around endosseous implants in posterior mandible: a 3D finite element analysis. Med Eng Phys 2006;28:199-213. https://doi.org/10.1016/j.medengphy.2005. 04.025

15. Cekiç C, Akça K, Cehreli MC. Effects of attachment design on strains around implants supporting overdentures. Quintessence Int 2007;38: e291-7.

16. Tanino F, Hayakawa I, Hirano S, Minakuchi S. Finite element analysis of stress-breaking attachments on maxillary implant-retained overdentures. Int J Prosthodont 2007;20:193-8.

17. Mariano LOH, Sartori EA, Broilo JR, Shinkai RS, Corso L, Marczak RJ Stresses in implant-supported overdentures with bone resorption: a 3-D finite element analysis. Rev. odonto ciênc. 2012;27:41-6. https://doi org/10.1590/S1980-65232012000100008
18. Michelinakis G, Barclay CW, Smith PW. The influence of interimplant distance and attachment type on the retention characteristics of mandibular overdentures on 2 implants: initial retention values. Int $J$ Prosthodont 2006;19:507-12.

19. Doukas D, Michelinakis G, Smith PW, Barclay CW. The influence of interimplant distance and attachment type on the retention characteristics of mandibular overdentures on 2 implants: 6-month fatigue retention values. Int J Prosthodont 2008:21:152-154.

20. Zitzmann NU, Marinello CP. A review of clinical and technical considerations for fixed and removable implant prostheses in the edentulous mandible. Int J Prosthodont 2002;15:65-72. 